\title{
Maternal consumption of organic trace minerals alters calf systemic and neutrophil mRNA and microRNA indicators of inflammation and oxidative stress
}

\author{
Carolina B. Jacometo, ${ }^{*} \dagger$ Johan S. Osorio,† Michael Socha,ł Marcio N. Corrêa, ${ }^{*}$ Fiorenzo Piccioli-Cappelli,§ \\ Erminio Trevisi,§ and Juan J. Loort ${ }^{1}$ \\ *NUPEEC (Núcleo de Ensino, Pesquisa e Extensão em Pecuária), Departamento de Clínicas Veterinária, Programa de Pós-Graduação \\ em Biotecnologia, Universidade Federal de Pelotas, 96160-000 Pelotas, RS, Brazil \\ †Mammalian NutriPhysioGenomics, Department of Animal Sciences and Division of Nutritional Sciences, University of Illinois, Urbana 61801 \\ $\ddagger Z i n p r o$ Corporation, 10400 Viking Drive, Eden Prairie, MN 55344 \\ §Istituto di Zootecnica, Facoltà di Scienze Agrarie, Alimentari e Ambientali, Università Cattolica del Sacro Cuore, 29122 Piacenza, Italy
}

\begin{abstract}
Organic trace mineral (ORG) supplementation to dairy cows in substitution of sulfate (INO) sources has been associated with improvement in immune function during stressful states such as the peripartal period. However, the effect of supplemental ORG during pregnancy on the neonatal calf is unknown. Therefore, our aim was to investigate the effects of ORG supplementation during late pregnancy on the immune system and growth of the neonatal calf. Of specific interest was the evaluation of inflammation-related microRNA (miRNA) and target gene expression in blood neutrophils as indicators of possible nutritional programming. Forty multiparous cows were supplemented for $30 \mathrm{~d}$ prepartum with $40 \mathrm{mg} / \mathrm{kg}$ of $\mathrm{Zn}, 20 \mathrm{mg} / \mathrm{kg}$ of $\mathrm{Mn}, 5$ $\mathrm{mg} / \mathrm{kg}$ of $\mathrm{Cu}$, and $1 \mathrm{mg} / \mathrm{kg}$ of Co from either organic (ORG) or sulfate (INO) sources (total diet contained supplemental $75 \mathrm{mg} / \mathrm{kg}$ of Zn, $65 \mathrm{mg} / \mathrm{kg}$ of Mn, $11 \mathrm{mg} /$ $\mathrm{kg}$ of $\mathrm{Cu}$, and $1 \mathrm{mg} / \mathrm{kg}$ of $\mathrm{Co}$, and additional $\mathrm{Zn}, \mathrm{Mn}$, and Co provided by sulfates), and a subset of calves (n $=8$ /treatment) was used for blood immunometabolic marker and polymorphonuclear leukocyte (PMNL) gene and miRNA expression analyses. Samples were collected at birth (before colostrum feeding), $1 \mathrm{~d}$ (24 $\mathrm{h}$ after colostrum intake), and 7 and $21 \mathrm{~d}$ of age. Data were analyzed as a factorial design with the PROC MIXED procedure of SAS. No differences were detected in BW, but maternal ORG tended to increase calf withers height. Calves from INO-fed cows had greater concentrations of blood glucose, GOT, paraoxonase, myeloperoxidase, and reactive oxygen metabolites. Antioxidant capacity also was greater in INO calves. The
\end{abstract}

Received January 19, 2015.

Accepted July 8, 2015.

${ }^{1}$ Corresponding author: jloor@illinois.edu
PMNL expression of toll-like receptor pathway genes indicated a pro-inflammatory state in INO calves, with greater expression of the inflammatory mediators MYD88, IRAK1, TRAF6, NFKB, and NFKBIA. The lower expression of miR-155 and miR-125b in ORG calves indicated the potential for maternal organic trace minerals in regulating the PMNL inflammatory response at least via alterations in mRNA and miRNA expression. Overall, these results indicate that maternal nutrition with organic trace minerals could alter the neonatal innate immune response at least in part via changes in gene and miRNA expression. Further studies involving inflammatory challenges during the neonatal period should be performed to determine the functional benefit of maternal organic trace minerals on the neonatal immune response.

Key words: epigenetics, fetal programming, nutrition, transcriptomics

\section{INTRODUCTION}

Trace mineral elements such as $\mathrm{Cu}, \mathrm{Cr}$, and $\mathrm{Zn}$ have important roles in the health and immunity of peripartal dairy cows (Spears and Weiss, 2008). Minerals have been commonly supplemented to cattle in the form of inorganic salts, preferably as sulfates; however, the development of organic forms of trace minerals, such as minerals complexed with AA, minimize the risk of mineral antagonism and enhance absorption efficiency (Swecker, 2014). Compared with a sulfate source, supplementing lactating cows with organic $\mathrm{Zn}$ resulted in greater immune response as well as improved milk yield (Wang et al., 2013).

The implications of trace mineral deficiency or impaired placental transfer of these minerals to fetal and neonatal ruminant metabolism have been studied for more than 30 yr (Hidiroglou, 1980). For instance, dairy calves supplemented with an injectable trace mineral 
complex containing $\mathrm{Se}, \mathrm{Cu}, \mathrm{Zn}$, and $\mathrm{Mn}$ experienced an increase in neutrophil (PMNL) and glutathione peroxidase activity, and a reduction in the incidence of diarrhea, pneumonia, and otitis (Teixeira et al., 2014). These constitute an example of the innate immune response of the animal, one in which cells such as PMNL are partly regulated via signaling pathways and changes in mRNA expression. An important inflammation-responsive pathway in the animal that connects the innate and adaptive immune response is the toll-like receptor (TLR). Its activation, and that of its target genes, leads to stimulation of several intermediate molecules and culminates with the synthesis of classical pro-inflammatory cytokines and chemokines (Wolowczuk et al., 2008; Chen et al., 2015).

Although changes in mRNA expression are known to partly control adaptations in PMNL due to inflammation, more recent studies have concluded that epigenetic modifications through microRNA (miRNA) are an important part of the regulation of several cellular process (Aguilera et al., 2010) that modulate PMNL function including regulation of senescence, differentiation, adherence capacity, and cytokine production (Gantier, 2013). These observations are of interest in the context of dairy cow nutrition because epigenetic markers are candidates for bearing the memory of specific intrauterine nutritional exposure causing alterations in long-term gene expression, and consequently inducing developmental adaptations in physiology and metabolism (Attig et al., 2010).

Mature miRNA are non-protein-coding small RNA $(\sim 20$ nucleotides length) that repress translational activity, promote destabilization of target mRNA, and regulate the abundance of mRNA target genes; however, these mechanisms remain under debate (Eulalio et al., 2008). It was reported in vitro using mouse P19 embryonal carcinoma cells that miR125-b can regulate mammalian neuronal differentiation by downregulating both translational efficiency and mRNA abundance of lin-28 (Wu and Belasco, 2005). Using a microarray approach with miR-transfected HeLa cells (miR-1 and miR-124), it was demonstrated that miRNA could reduce the levels of many of their target transcripts, not just the amount of protein derived from these transcripts (Lim et al., 2005).

The general hypothesis of the present study was that maternal supplementation with organic trace minerals would improve neonatal calf metabolism and immune function reflected in the profiles of systemic blood biomarkers, mRNA, and microRNA in PMNL, and measures of growth and performance from birth through weaning. The possible epigenetic regulation through the action of miRNA in the pro-inflammatory signaling pathway also was evaluated.

\section{MATERIALS AND METHODS}

All the procedures for this study were conducted in accordance with the protocol approved by the Institutional Animal Care and Use Committee of the University of Illinois (protocol \#12097).

\section{Maternal Treatments}

The experiment was conducted as a randomized complete blocked design with 40 multiparous Holstein cows blocked according to parity, previous lactation milk yield, and expected day of parturition. All cows received a common lactation diet $(1.76 \mathrm{Mcal} / \mathrm{kg}$ of DM and $16.7 \% \mathrm{CP}$ ) during the last $60 \mathrm{~d}$ of lactation before dry-off, and a common early-dry period diet (1.1 Mcal/ $\mathrm{kg}$ of DM, $14.5 \% \mathrm{CP}$ ) from -50 to $-30 \mathrm{~d}$ relative to parturition. Both diets were supplemented at $100 \%$ of NRC (2001) requirements with $\mathrm{Zn}, \mathrm{Mn}, \mathrm{Cu}$, and Co in the form of an inorganic trace mineral mix. All cows received the same diet (1.5 Mcal $/ \mathrm{kg}$ of DM, $15 \% \mathrm{CP}$ ) from $-30 \mathrm{~d}$ to parturition (close-up period).

The close-up diet was partially supplemented with an inorganic trace mineral mix of $\mathrm{Zn}, \mathrm{Mn}$, and $\mathrm{Cu}$ to supply 35,45 , and $6 \mathrm{mg} / \mathrm{kg}$, respectively, of the total dietary minerals. Cows were randomly assigned to an oral administration of a bolus once daily at the time of feeding the TMR. This contained a mix of either inorganic (INO, $\mathrm{n}=20$ ) or organic (AvailaZn Zn AA complex, AvailaMn Mn AA complex, AvailaCu Cu AA complex, and CoPro cobalt glucoheptonate; Zinpro Corporation, Eden Prairie, MN; ORG, $\mathrm{n}=20) \mathrm{Zn}, \mathrm{Mn}, \mathrm{Cu}$, and Co to achieve $75,65,11$, and $1 \mathrm{mg} / \mathrm{kg}$, respectively, in diet DMI. After birth, calves were fed a common diet and managed similarly. Hence, any observed treatment effects are attributed to maternal nutrition during the last $30 \mathrm{~d}$ of gestation.

\section{Animal Management and Calf Enrollment Criteria}

During the dry period, cows were housed in a ventilated, sand-bedded free-stall barn, with a photoperiod of 8 $\mathrm{h}$ of light and $16 \mathrm{~h}$ of dark. Diets were fed for ad libitum intake as a TMR once daily, between 0600 and 0800 $\mathrm{h}$, using an individual gate feeding system (American Calan, Northwood, NH). As cows began demonstrating signs of impending parturition, they were moved to an individual maternity pen bedded with straw. After parturition, cows were moved within $2 \mathrm{~h}$ to an individual chute and then milked with a porta-milker vacuum pump (catalog no. Z15664N, Nasco, Fort Atkinson, WI). Colostrum volume was recorded and IgG content was estimated based on specific gravity with a bovine colostrometer (catalog no. C10978N, Nasco). 
A subset of calves was selected $(n=8 /$ group) if they and their dams fulfilled all the following criteria: (1) single calf, (2) calving difficulty score $<3$, (3) colostrum quality assessed by a bovine colostrometer of $>60$ $\mathrm{mg} / \mathrm{L}$ of $\mathrm{IgG}$, (4) dam produced at least $3.8 \mathrm{~L}$ of a good quality first colostrum, and (5) heifer calf birth weight $>36 \mathrm{~kg}$ (Johnson et al., 2007). On d 7 and 21, calves were bled $\sim 3 \mathrm{~h}$ after the morning feeding. Although a power test was not performed, based on previous work (e.g., papers cited in Hammon et al., 2012; Osorio et al., 2012), a total of 8 calves per group were deemed adequate.

After birth, calves were weighed, had the navel disinfected with a $7 \%$ tincture of iodine solution (First Priority Inc., Elgin, IL), vaccinated with TSV II (Pfizer Inc., New York, NY) via nostril application, and received $3.8 \mathrm{~L}$ of first milking colostrum from the respective dam within $2 \mathrm{~h}$ after birth. Animals did not receive supplemental vitamin $\mathrm{A}$ or $\mathrm{D}, \mathrm{Fe}$, or Se. Calves were offered first milking colostrum again on the second feeding at $4 \mathrm{~h}$ after birth if colostrum intake had not reached the $3.8 \mathrm{~L}$ required. Calves were housed in individual outdoor hutches bedded with straw, fed twice daily with a milk replacer (Advance Excelerate, Milk Specialties, Carpentersville, IL; $28.5 \%$ CP, $15 \%$ fat; from 1 to $10 \mathrm{~d}$ of age: $520 \mathrm{~g} / \mathrm{d}$; 11 to $20 \mathrm{~d}$ of age: $680 \mathrm{~g} / \mathrm{d} ; 21$ to $35 \mathrm{~d}$ of age: $840 \mathrm{~g} / \mathrm{d}$; and 36 to $42 \mathrm{~d}$ of age: $420 \mathrm{~g} / \mathrm{d}$ in a single feeding) and had ad libitum access to a starter grain mix $(19.9 \% \mathrm{CP}, 13.5 \% \mathrm{NDF})$. Intake was recorded daily. Health checks including fecal score were recorded daily until weaning [scale 1-4, 1: firm, well formed (not hard); 2: soft, pudding-like; 3: runny, pancake batter; 4: liquid, splatters; Osorio et al., 2012], and rectal temperature was recorded daily until $21 \mathrm{~d}$ of age. Growth performance including BW and withers height (WH) were recorded weekly. Calves were weaned at $42 \mathrm{~d}$ of age.

\section{Sample Collection}

Calf blood samples were collected from a jugular vein using 20-gauge BD Vacutainer needles (Becton Dickinson, Franklin Lakes, NJ) before receiving colostrum (baseline), $24 \mathrm{~h}$ after receiving colostrum, and 7 and $21 \mathrm{~d}$ after birth. At each time point, a total of 120 $\mathrm{mL}$ of total blood were collected in vacutainer tubes (10 mL, BD Vacutainer, Becton Dickinson) containing serum clot activator $(10 \mathrm{~mL})$, sodium heparin (10 $\mathrm{mL}$ ), or solution A of trisodium citrate, citric acid, and dextrose (ACD; $100 \mathrm{~mL}$ ). After blood collection, tubes with ACD and sodium heparin were placed on ice and tubes with clot activator were kept at room temperature until centrifugation $(\sim 30 \mathrm{~min})$. Serum and plasma were obtained by centrifugation of clot activa- tor and sodium heparin tubes, respectively, at 1,900 $\times$ $g$ for $15 \mathrm{~min}$ at $4^{\circ} \mathrm{C}$. Serum and plasma were aliquoted and stored at $-80^{\circ} \mathrm{C}$ until further analysis according to the manufacturer's specifications for determination of blood metabolites, oxidative stress biomarkers, and acute-phase proteins (APP). The RNA from PMNL was harvested from $100 \mathrm{~mL}$ of blood collected in ACD vacutainer tubes. It is estimated that calves in the present study lost $240 \mathrm{~mL}$ of blood during the first 2 samplings, which is substantially below the limit they could tolerate (i.e., $10-15 \mathrm{~mL} / \mathrm{kg}$ of BW; Rosenberg, 1979). Furthermore, no visual or clinical signs of health problems were observed after collection of the blood, and the biomarkers analyzed did not indicate any alteration in blood homeostasis. All calves had a normal growth rate, as expected.

\section{Blood Metabolites, APP, and Oxidative Stress Biomarkers}

Blood samples were analyzed within 3 mo of collection for several biomarkers of energy metabolism and liver function, inflammation, oxidative stress and antioxidant capacity, and minerals. These included albumin (catalog no. 0018250040), cholesterol (catalog no. 0018250540), bilirubin (catalog no. 0018254640), creatinine (catalog no. 0018255540), urea (catalog no. 0018255440), glutamic-oxaloacetic transaminase (GOT; catalog no. 0018257540), $\gamma$-glutamyltransferase (GGT; catalog no. 0018257640), and glucose (catalog no. 0018250840) using the IL Test purchased from Instrumentation Laboratory Spa (Werfen Co., Milan, Italy) in the ILAB 600 clinical auto-analyzer (Instrumentation Laboratory, Lexington, MA). Haptoglobin was analyzed using the method described in Skinner et al. (1991), whereas ceruloplasmin was determined following a minor modification of the method proposed by Sunderman and Nomoto (1970), where the acetate buffer was changed to $0.8 \mathrm{M}, \mathrm{pH} 6.4$, and contained $0.31 \%$ Na-EDTA. Reactive oxygen metabolites (ROM) were analyzed with the d-ROMs-test (cod. MC002), purchased from Diacron (Grosseto, Italy). Antioxidant potential was assessed as ferric reducing antioxidant power (FRAP) using the colorimetric method of Benzie and Strain (1996). Nitric oxide (NOx) and constituents [nitrite $\left(\mathrm{NO}_{2}^{-}\right)$and nitrate $\left(\mathrm{NO}_{3}^{-}\right)$] and paraoxonase (PON) were determined according methods previously described by Trevisi et al. (2013). Myeloperoxidase (MPO) was determined as previously described (Bionaz et al., 2007), via colorimetry based on the reaction of MPO contained in the plasma sample with hydrogen peroxide, which forms $\mathrm{H}_{2} \mathrm{O}$ and $\mathrm{O}^{-}$; the $\mathrm{O}^{-}$dianisidine dihydrochloride, and electron donor, reacts with the $\mathrm{O}^{-}$, releasing $\mathrm{H}_{2} \mathrm{O}$ and a colored compound. Nonesteri- 
fied fatty acids and BHBA were measured using kits from Wako Chemicals and Randox Laboratories Ltd., respectively, following the procedures described previously (Bionaz et al., 2007; Trevisi et al., 2012; Osorio et al., 2013). Serum amyloid A (SAA) concentration was assessed with a commercial ELISA immunoassay kit (Tridelta Development Ltd., Maynooth, Co. Kildare, Ireland). Total antioxidants were assessed through the oxygen radical absorbance capacity (ORAC) assay. This method measures a fluorescent signal from a probe (fluorescein) that decreases in the presence of radical damage (Cao and Prior, 1999). Retinol and tocopherol were determined as previously described (Bionaz et al., 2007). Bovine IL-6 plasma concentration was determined by a colorimetric sandwich ELISA using a Bovine IL-6 Screening Set, using pretitered, matched pairs of coating and detection antibodies and a calibrated recombinant protein standard (\#ESS0029 Endogen, Pierce, Rockford, IL).

Minerals were extracted adding $0.3 \mathrm{~mL}$ of trichloracetic acid $(10 \% \mathrm{vol} / \mathrm{vol})$ to $0.3 \mathrm{~mL}$ of plasma, sample was mixed and centrifuged at 3,500 $\times g$ for $10 \mathrm{~min}$ at $4^{\circ} \mathrm{C}$. A $0.3 \mathrm{~mL}$ of superrnatant was added to $2.7 \mathrm{~mL}$ of Millipore water and mixed. Copper, Fe, Mn, and $\mathrm{Zn}$ in final solution were determined by inductively coupled plasma optical emission spectrometry (ICP-OES 5100, Agilent Technologies, Victoria, Australia) fitted with cyclonic chamber in which samples were introduced with SeaSpray nebulizer (Agilent Technologies). Trichloracetic acid solution at the same concentration of the samples was used as a blank and to prepare the calibration curve diluting external standard (Merck, Darmstadt, Germany) to 5, 10, 50, and $100 \mathrm{ppb}$. Instrumental detection limits were $0.35,0.10,0.06,0.25$ $\mathrm{ppb}$ for $\mathrm{Cu}, \mathrm{Fe}, \mathrm{Mn}$, and $\mathrm{Zn}$, respectively. Accuracy of results was verified using a mineralized solution of SRM 1577b (National Institute of Standards and Technology).

\section{PMNL Isolation and Viability Analysis}

Complete details of PMNL isolation and viability analysis are included in the Supplemental File (http:// dx.doi.org/10.3168/jds.2015-9359). Briefly, neutrophils were isolated from whole blood $(100 \mathrm{~mL})$ collected in ACD-containing vacutainer tubes within $1 \mathrm{~h}$ of sample collection. An aliquot $(20 \mu \mathrm{L})$ obtained during the PMNL isolation process was used for PMNL quantification and viability using a granulocyte primary antibody (CH138A, Veterinary Microbiology and Pathology, Washington State University, Pullman, WA) followed by a second antibody (Goat Anti-Mouse IgM, Human ads-PE, Southern Biotech, Birmingham, AL). Cells were fixed with $150 \mu \mathrm{L}$ of $4 \%$ paraformaldehyde
(Sigma-Aldrich, St. Louis, MO) and preserved at $4^{\circ} \mathrm{C}$ until flow cytometry reading (LSR II, Becton Dickinson, San Jose, CA). This procedure was performed to ensure good quality samples. All samples harvested and used for analysis contained more than $80 \%$ neutrophils and had at least $90 \%$ viability.

\section{mRNA and miRNA Isolation}

For the PMNL extraction, the miRNeasy kit (Qiagen, Hilden, Germany) was used following the manufacturer's protocols, allowing the recovery of both mRNA and miRNA for measuring the expression of the desired targets (Table 1). Samples were treated on-column with DNaseI (Qiagen); quantification was accessed using the NanoDrop ND-1000 (NanoDrop Technologies, Rockland, DE), and RNA quality was measured using an Agilent 2100 Bioanalyzer (Agilent, Santa Clara, CA). All samples had an RNA integrity number factor greater than 6 . Information required by the minimum information for publication of quantitative real-time PCR experiments (Bustin et al., 2009) guidelines are provided in the Supplemental Materials (http://dx.doi. org/10.3168/jds.2015-9359).

\section{Target Gene cDNA Synthesis and Quantitative PCR}

All the details for cDNA synthesis, quantitative PCR, and primer design can be found in the supplementary material published by Osorio et al. (2013). For this study, GOLGA5, SMUG1, and OSBPL2 were used as internal control genes, which have been previously used to normalize PMNL gene expression data (Moyes et al., 2010; Seo et al., 2013). The geometric mean of the internal control genes was used to normalize the expression data. The stability of the normalization factor was assessed with geNorm software (Vandesompele et al., 2002 ) with a favorable final pairwise variation of 0.20 .

\section{miRNA Procedures}

For cDNA synthesis, we used the qScript miRNA cDNA synthesis kit (Quanta Biosciences, Gaithersburg, MD). Each reaction started with $500 \mathrm{ng}$ of total RNA, mixed with $2 \mu \mathrm{L}$ of Poly (A) Tailing Buffer $(5 \times), 1 \mu \mathrm{L}$ of Poly (A) Polymerase, and $7 \mu \mathrm{L}$ of RNase/DNase-free water. The mixture was incubated at $37^{\circ} \mathrm{C}$ for $20 \mathrm{~min}$ and then $70^{\circ} \mathrm{C}$ for $5 \mathrm{~min}$. A second mix containing $9 \mu \mathrm{L}$ of miRNA cDNA Reaction Mix and $1 \mu \mathrm{L}$ of qScript Reverse Transcriptase was added and incubated at $42^{\circ} \mathrm{C}$ for $20 \mathrm{~min}$ and then $85^{\circ} \mathrm{C}$ for $5 \mathrm{~min}$. A pool of cDNA samples was used to prepare the 6-point standard curve (dilution 1:4). Then cDNA samples were also diluted 1:4 with DNase/RNase-free water. A combination of 1 
Table 1. Genes and microRNA selected for transcript profiling in bovine neutrophils

\begin{tabular}{ll}
\hline & HUGO gene \\
Gene name & symbol \\
\hline Interleukin 1, $\beta$ & IL1B \\
Interleukin-1 receptor-associated kinase 1 & IRAK1 \\
Myeloperoxidase & MPO \\
Myeloid differentiation primary response gene (88) & MYD88 \\
Nuclear factor (erythroid-derived 2)-like 2 & NFE2L2 \\
Nuclear factor of kappa light polypeptide gene enhancer in B-cells 1 & NFKB1 \\
Nuclear factor of kappa light polypeptide gene enhancer in B-cells inhibitor,, & NFKBIA \\
Nitric oxide synthase 2, inducible & NOS2 \\
Selectin L & SELL \\
Superoxide dismutase 1, soluble & SOD1 \\
Toll-like receptor 2 & TLR2 \\
Toll-like receptor 4 & TLR4 \\
Tumor necrosis factor- $\alpha$ & TNF \\
TNF receptor-associated factor 6 & TRAF6 \\
Z-DNA binding protein 1 & ZBP1 \\
MicroRNA miR-125b & MIR125b \\
MicroRNA miR-146a & MIR146a \\
MicroRNA miR-155 & MIR155 \\
MicroRNA miR-223 & MIR223 \\
MicroRNA miR-9 & \\
\hline
\end{tabular}

$\mu \mathrm{L}$ of diluted $\mathrm{cDNA}$ with $9 \mu \mathrm{L}$ of the mix containing of $5.25 \mu \mathrm{L}$ of Perfecta SYBR Green Fast Mix (Quanta Biosciences), $0.45 \mu \mathrm{L}$ each of $10 \mu M$ sequence-specific forward primer and Universal PCR Primer (Quanta Biosciences), and $3.85 \mu \mathrm{L}$ of DNase/RNase-free water were added to each well of a MicroAmp Optical 384-Well Reaction Plate (Applied Biosystems, Grand Island, NY). The reactions were performed in an ABI Prism 7900 HT SDS instrument (Applied Biosystems) under the following thermocycler conditions: $95^{\circ} \mathrm{C}$ for 2 min, and 40 cycles of $95^{\circ} \mathrm{C}$ for $5 \mathrm{~s}$ and $60^{\circ} \mathrm{C}$ for $30 \mathrm{~s}$, followed by a dissociation curve step $\left(95^{\circ} \mathrm{C}\right.$ for $15 \mathrm{~s}, 60^{\circ} \mathrm{C}$ for $15 \mathrm{~s}$, and $95^{\circ} \mathrm{C}$ for $\left.15 \mathrm{~s}\right)$. The miR-let7a, miR-103 and miR-191 were used as internal controls, and their geometric mean was used to normalized the miRNA expression data.

All primers, PCR products, and PCR efficiencies are reported in the Supplementary Material, Tables S1 to S5 (http://dx.doi.org/10.3168/jds.2015-9359). The model of the TLR pathway under miRNA control is illustrated in the Supplementary Material.

\section{Statistical Analysis}

Data were analyzed with the PROC MIXED procedure of SAS 9.4 (SAS Institute Inc., Cary, NC). Fixed effects in the model were treatment, day, or week (for $\mathrm{BW}, \mathrm{WH}$, rectal temperature, fecal score, and starter intake), and their interaction [treatment $(\mathbf{T}) \times$ day $(\mathbf{D}), \mathrm{T} \times$ week $(\mathbf{W})]$. Random effect was calf within diet. The exponential correlation covariance structure SP for repeated measures was used for analysis of blood metabolites and relative gene and miRNA expression.
Blood biomarkers and gene/miRNA expression results were $\log _{2}$-scale transformed if needed to comply with normal distribution of residuals. Least squares means separation was performed using the PDIFF statement. Statistical significance was declared at $P \leq 0.05$ and tendencies at $P \leq 0.10$. For ease of interpretation, the least squares means reported in Tables 2 and 3 and Supplementary Tables S7 and S8 (http://dx.doi.org/10.3168/ jds.2015-9359) are the $\log _{2}$ back-transformed means that resulted from the statistical analysis.

\section{RESULTS}

\section{Growth Performance and Health}

Colostral IgG was not affected $(P=0.87)$ by diet and averaged $96.7 \pm 6.2 \mathrm{mg}$ of $\mathrm{IgG} / \mathrm{mL}$. Similarly, apparent efficiency of absorption was not affected $(P=0.93)$ by maternal diet, averaging $35.9 \pm 3.1 \%$.

Maternal supplementation with ORG did not affect $(P>0.05) \mathrm{BW}$ at birth or throughout the experiment. However, regardless of treatment, a linear increase in BW $(P<0.001)$ occurred in both groups (Figure 1$)$. In contrast, WH tended to be greater overall $(P=0.063)$ in ORG calves than INO. An overall increase $(P<$ 0.001) across time was observed for WH (Figure 1).

No treatment effect $(P>0.05)$ was observed for starter intake despite the increase in consumption through time $(P<0.001)$ in both groups (Supplementary Table S6; http://dx.doi.org/10.3168/jds.2015-9359). Rectal temperature decreased $(P=0.032)$ from birth to $2 \mathrm{wk}$ in both groups; however, it tended to be lower $(P=$ 0.069) in ORG calves (Supplementary Table S6; http:// 
¿̀ Table 2. Blood immunometabolic biomarkers in calves born to dams fed a conventional diet supplemented with only inorganic (INO) or inorganic plus organic (ORG) trace minerals during the last $30 \mathrm{~d}$ prepartum

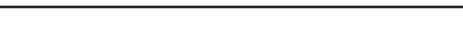

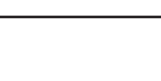

Treatment

\begin{tabular}{c} 
\\
\hline 0 \\
\hline \\
$2.06^{\mathrm{B}, \mathrm{c}}$ \\
$4.09^{\mathrm{A}, \mathrm{c}}$ \\
1.00 \\
1.10 \\
0.04 \\
0.04 \\
7.63 \\
7.77 \\
$4.53^{\mathrm{a}}$ \\
$3.79^{\mathrm{b}}$ \\
4.03 \\
4.07 \\
5.40 \\
5.61 \\
3.87 \\
3.78 \\
0.74 \\
0.79 \\
29.7 \\
31.2 \\
\\
0.03 \\
0.29 \\
0.40 \\
0.46 \\
$6.3^{\mathrm{c}}$ \\
$10.2^{\mathrm{c}}$ \\
41.94 \\
51.49 \\
275.7 \\
133.5 \\
\\
\hline
\end{tabular}

Day of ag

age

\begin{tabular}{|c|c|c|c|}
\hline & \multicolumn{3}{|c|}{$P$-value ${ }^{3}$} \\
\hline $\mathrm{EM}^{2}$ & $\mathrm{~T}$ & $\mathrm{D}$ & $\mathrm{T} \times \mathrm{D}$ \\
\hline
\end{tabular}

Energy metabolism and liver function

ORG
INO
ORG
INO
ORG
INO
ORG
INO
ORG
INO
ORG
INO
ORG
INO
ORG
INO
ORG
INO
ORG
INO

\section{Inflammation}

Ceruloplasmin, $\mu \mathrm{mol} / \mathrm{L}$

Haptoglobin, g/L

Paraoxonase, $\mathrm{U} / \mathrm{mL}$

$\mathrm{SAA}, \mu \mathrm{g} / \mathrm{mL}$

IL-6, pg/mL

Oxidative stress and antioxidants

Myeloperoxidase $(\log 2), \mathrm{U} / \mathrm{L}$

ROMt (log2), mg $\mathrm{H}_{2} \mathrm{O}_{2} / 100 \mathrm{~mL}$

FRAP, $\mu \mathrm{mol} / \mathrm{L}$

NOx, $\mu \mathrm{mol} / \mathrm{L}$

$\mathrm{NO}_{2}{ }^{-}, \mu \mathrm{mol} / \mathrm{L}$

$\mathrm{NO}_{3}{ }^{-}, \mu \mathrm{mol} / \mathrm{L}$

ORAC, TE mol/L

Retinol, $\mu \mathrm{g} / 100 \mathrm{~mL}$

$\begin{array}{lr}\text { ORG } & 0.03 \\ \text { INO } & 0.29 \\ \text { ORG } & 0.40 \\ \text { INO } & 0.46 \\ \text { ORG } & 6.3^{\mathrm{c}} \\ \text { INO } & 10.2^{\mathrm{c}} \\ \text { ORG } & 41.94 \\ \text { INO } & 51.49 \\ \text { ORG } & 275.7 \\ \text { INO } & 133.5\end{array}$

$\begin{array}{lllllll}8.03^{\mathrm{a}} & 6.12^{\mathrm{b}} & 5.58^{\mathrm{b}} & 0.37 & 0.001 & <0.001 & 0.017 \\ 8.95^{\mathrm{a}} & 5.86^{\mathrm{b}} & 6.39^{\mathrm{b}} & 0.34 & & & \\ 0.32 & 0.40 & 0.17 & 0.08 & 0.808 & <0.001 & 0.781 \\ 0.30 & 0.39 & 0.16 & 0.07 & & & \\ 0.06 & 0.08 & 0.11 & 0.01 & 0.361 & <0.001 & 0.112\end{array}$

$\mathrm{ND}^{4}$
$\mathrm{ND}^{4}$
$\mathrm{ND}^{4}$

INO

ORG

INO

ORG
INO

ORG

INO

ORG

ORG

INO

ORG

INO
ORG

INO

$\mathrm{ND}^{4}$
$\mathrm{ND}^{4}$
256
293
14.44
15.03
6.07
6.92
8.35
8.70
8.89
8.96
5.45
6.18

$\begin{array}{ll}0.06 & 0.08 \\ 0.06 & 0.08\end{array}$

$\begin{array}{lllllll}0.06 & 0.08 & 0.15 & 0.01 & & & \\ 6.78 & 6.64 & 6.42 & 0.08 & 0.445 & <0.001 & 0.756 \\ 6.79 & 6.71 & 6.43 & 0.07 & & & \end{array}$

$\begin{array}{llll}6.79 & 6.71 & 6.43 & 0.07 \\ 3.25^{\mathrm{b}} & 3.21^{\mathrm{b}} & 3.96^{\mathrm{ab}} & 0.36\end{array}$

$3.25^{\mathrm{b}} \quad 3.21^{\mathrm{b}} \quad 3.96^{\mathrm{ab}} \quad 0.36$

$3.67^{\mathrm{b}}$

$4.28 \quad 3.16$

$\begin{array}{ll}4.34 & 3.56\end{array}$

6.72

6.79

11.22

11.40

1.00
1.02

1.02
25.9

26.6

0.86
1.24

1.24
0.40

0.41

$12.1^{\mathrm{cc}}$

$15.6^{\mathrm{c}}$
243.9

270.5
453.3

453.3
493.9

5.38

5.81

8.74

$\begin{array}{ll}9.16 & 6.88 \\ 1.58 & 2.37\end{array}$

$\begin{array}{ll}1.58 & 2.58\end{array}$

$\begin{array}{cc}1.69 & 3.00 \\ 29.2 & 31.5\end{array}$

$\begin{array}{ll}30.4 & 31.5 \\ & 32.8\end{array}$

2.76

$\begin{array}{ll}2.91 & 2.66 \\ 0.51 & 2.60\end{array}$

$\begin{array}{ll}0.51 & 0.60 \\ 0.47\end{array}$

$\begin{array}{rr}0.47 & 0.33 \\ 17.2^{\mathrm{b}} & 42.5^{\mathrm{B}, \mathrm{a}}\end{array}$

$17.2^{\mathrm{b}}$
$23.7^{\mathrm{b}}$

$23.7^{\mathrm{b}}$
267.2

$56.9^{\mathrm{A}}$

$\begin{array}{ll}307.6 & 149.6 \\ 300.2 & 141.9\end{array}$

$300.2 \quad 285.6$

294.8

4.62
5.38
0.09
0.40
198
220
20.89
28.05
8.91
13.51
11.97
16.11
10.59
11.55
10.12
14.61

5.04
5.83
2.08
2.57
165
218
16.95
22.04
6.62
9.65
9.67
12.38
11.57
12.56
13.75
18.52

0.968

$<0.001$

0.039

$\begin{array}{ll}2.20 & 0.20\end{array}$

$0.170<0.001 \quad 0.756$

$0.015<0.001 \quad 0.611$

$\begin{array}{lll}0.422<0.001 & 0.444\end{array}$

$\begin{array}{lll}0.268<0.001 & 0.345\end{array}$

$0.113<0.001 \quad 0.192$

$0.345<0.001 \quad 0.468$

$\begin{array}{lll}0.894 & 0.251 & 0.768\end{array}$

$<0.001<0.001 \quad 0.053$

$0.398<0.001 \quad 0.652$

$\begin{array}{lll}0.796 & 0.056 & 0.607\end{array}$

5.86

6.28
2.22
2.40

165

213

26.54
27.65

27.65
11.98

11.75

14.59

15.81

11.04
12.79

$\begin{array}{ll}15.64 & 3.38 \\ 24.78 & 3.31\end{array}$

$\begin{array}{rrr}0.003 & 0.013 & 0.822 \\ 0.083 & <0.001 & 0.712 \\ 0.043 & <0.001 & 0.746 \\ 0.229 & 0.006 & 0.852 \\ 0.216 & 0.016 & 0.857 \\ 0.228 & 0.002 & 0.712 \\ 0.109 & <0.001 & 0.382 \\ 0.335 & <0.001 & 0.529\end{array}$


dx.doi.org/10.3168/jds.2015-9359). Although no overall treatment effect $(P=0.69)$ was found, INO calves had greater $(\mathrm{T} \times \mathrm{W}, P=0.060)$ fecal score than ORG calves at 4 wk of age. Regardless of treatment effect, calves experienced the greatest $(P<0.001)$ fecal score during wk 1 of age, followed by a gradual decrease $(P$ $<0.001$ ) until 7 wk (Supplementary Table S6; http:// dx.doi.org/10.3168/jds.2015-9359). In addition, all calves always consumed all the milk replacer that was offered.

\section{Blood Immunometabolic Biomarkers}

Main effects of diet, time, and interactions for blood immunometabolic biomarkers are reported in Table 2 . Supplementary Table S7 (http://dx.doi.org/10.3168/ jds.2015-9359) reports effects due to day. Overall, calves born to dams supplemented with ORG had lower glucose concentrations $(P=0.001)$ and this was particularly evident at birth $(\mathrm{T} \times \mathrm{D}, P=0.017)$. Subsequently, change in glucose concentrations were similar with a rapid increase from birth to $1 \mathrm{~d}$ of life followed by stabilization after 1 wk of age $(P<0.001)$.

The NEFA and creatinine decreased from birth to $1 \mathrm{~d}$ of age $(P<0.001)$, with no treatment effect $(P>0.05)$, whereas BHBA concentration increased over time $(P<$ 0.001). Urea decreased from birth to $7 \mathrm{~d}$ of age $(P<$ 0.001) in both groups. The ORG calves had an abrupt decrease in urea from birth to $1 \mathrm{~d}$ of age, and INO calves had a gradual decrease until $7 \mathrm{~d}$ of age $(\mathrm{T} \times \mathrm{D}$, $P=0.039)$. No difference were observed from birth to $1 \mathrm{~d}$ of age in bilirubin concentrations $(P>0.05)$, and a gradual decrease regardless of treatment was observed until $21 \mathrm{~d}(P<0.001)$.

The hepatic enzymes GOT and GGT had a marked increase from birth to $1 \mathrm{~d}$ of age, followed by a gradual decrease $(P<0.001)$. An overall treatment effect $(P$ $=0.015)$ was observed in GOT associated with lower concentration in ORG calves, which had a more pronounced decrease from 1 to $7 \mathrm{~d}$ of age.

Compared with INO, ORG calves had lower paraoxonase $(P<0.001)$, MPO $(P=0.003)$, and FRAP $(P=0.043)$ concentrations, and tended to have lower $\operatorname{ROM}(P=0.083)$ and ORAC $(P=0.109)$. No treatment effect was observed for albumin, ceruloplasmin, cholesterol, haptoglobin, SAA, and IL-6 $(P>0.05)$. However, ceruloplasmin and cholesterol increased over time $(P<0.001)$, and SAA and IL-6 had a marked increase from birth to $1 \mathrm{~d}$ of age $(P<0.001$ and $P=$ 0.056 , respectively). Concentration of ORAC, retinol, tocopherol, NOx, and constituents $\left(\mathrm{NO}_{2}{ }^{-}\right.$and $\left.\mathrm{NO}_{3}{ }^{-}\right)$ increased over time $(P<0.05)$.

No effect $(P>0.05)$ was present of maternal diet on the evaluated blood mineral concentrations. At birth, 
concentrations of all minerals were numerically greater in ORG than INO. A time effect was observed for $\mathrm{Cu}$ $(P<0.001)$ and $\mathrm{Zn}(P<0.001)$ concentrations because of an increase over time, whereas concentration of $\mathrm{Fe}$ decreased $(P<0.001)$.

\section{Gene and miRNA Gene Expression}

TLR Pathway. Data on mRNA and miRNA in PMNL over time are reported in Table 3. Despite the overall greater expression of TLR2 in ORG calves $(P=$ 0.018 ), an overall decrease occurred of several genes that participate in the pro-inflammatory cytokine response. The calves in ORG had lower expression of IRAK1 $(P$ $=0.050), \operatorname{NFKB1}(P=0.031)$, and NFKBIA $(P=$ $0.047)$ and tended to have lower $M Y D 88(P=0.059)$ and TRAF6 $(P=0.063)$ expression. Although only a trend for treatment effect was observed for $I L 1 B(P=$ 0.103), the expression of TNF had an interaction $(\mathrm{T} \times$ $\mathrm{D}, P=0.056)$ namely due to lower $(P=0.017)$ expres-

Table 3. Relative mRNA expression of genes related to pro-inflammatory signaling cascades, cell adhesion, pathogen recognition, oxidative stress, and microRNA in calves born to dams fed a conventional diet supplemented with only inorganic (INO) or inorganic plus organic (ORG) trace minerals during the last $30 \mathrm{~d}_{\text {prepartum }}{ }^{1}$

\begin{tabular}{|c|c|c|c|c|c|c|c|c|c|}
\hline \multirow[b]{2}{*}{ Item } & \multirow[b]{2}{*}{ Treatment } & \multicolumn{4}{|c|}{ Day of age } & \multirow[b]{2}{*}{$\mathrm{SEM}^{2}$} & \multicolumn{3}{|c|}{$P$-value ${ }^{3}$} \\
\hline & & 0 & 1 & 7 & 21 & & $\mathrm{~T}$ & $\mathrm{D}$ & $\operatorname{Trt} \times \mathrm{D}$ \\
\hline \multicolumn{10}{|l|}{ Gene } \\
\hline \multirow[t]{2}{*}{ TLR2 } & ORG & 5.70 & 5.55 & 5.31 & 4.95 & 0.21 & 0.018 & $<0.001$ & 0.348 \\
\hline & INO & 5.26 & 5.33 & 5.19 & 4.13 & 0.21 & & & \\
\hline \multirow[t]{2}{*}{$T L R 4$} & ORG & 5.48 & 5.38 & 5.48 & $5.48^{\mathrm{A}}$ & 0.20 & 0.367 & 0.035 & 0.033 \\
\hline & INO & $5.74^{\mathrm{a}}$ & $5.26^{\mathrm{a}}$ & $5.48^{\mathrm{a}}$ & $4.71^{\mathrm{B}, \mathrm{b}}$ & 0.20 & & & \\
\hline \multirow[t]{2}{*}{$M Y D 88$} & ORG & 5.11 & 5.28 & 5.25 & 5.19 & 0.19 & 0.059 & 0.709 & 0.810 \\
\hline & INO & 5.57 & 5.58 & 5.57 & 5.30 & 0.19 & & & \\
\hline \multirow[t]{2}{*}{$I R A K 1$} & ORG & 4.64 & 5.34 & 5.19 & 5.38 & 0.23 & 0.050 & $<0.001$ & 0.232 \\
\hline & INO & 5.31 & 5.60 & 5.49 & 6.24 & 0.23 & & & \\
\hline \multirow[t]{2}{*}{$T R A F 6$} & ORG & 5.23 & 5.35 & 5.47 & 5.41 & 0.13 & 0.063 & 0.009 & 0.519 \\
\hline & INO & 5.31 & 5.62 & 5.77 & 5.75 & 0.13 & & & \\
\hline \multirow[t]{2}{*}{$N F K B 1$} & ORG & 4.77 & 5.36 & 5.32 & 5.50 & 0.12 & 0.031 & $<0.001$ & 0.351 \\
\hline & INO & 5.29 & 5.45 & 5.50 & 5.75 & 0.12 & & & \\
\hline \multirow[t]{2}{*}{$N F K B I A$} & ORG & 5.80 & 5.15 & 5.51 & 5.50 & 0.19 & 0.047 & $<0.001$ & 0.636 \\
\hline & INO & 6.34 & 5.68 & 5.83 & 5.60 & 0.19 & & & \\
\hline \multirow[t]{2}{*}{$I L 1 B$} & ORG & 4.59 & 5.54 & 5.84 & 6.03 & 0.26 & 0.103 & $<0.001$ & 0.800 \\
\hline & INO & 4.21 & 5.35 & 5.64 & 5.43 & 0.26 & & & \\
\hline \multirow[t]{2}{*}{$T N F$} & ORG & $4.10^{\mathrm{b}}$ & $5.67^{\mathrm{a}}$ & $4.80^{\mathrm{b}}$ & $5.22^{\mathrm{B}, \mathrm{ab}}$ & 0.46 & 0.299 & $<0.001$ & 0.056 \\
\hline & INO & $4.32^{\mathrm{c}}$ & $5.60^{\mathrm{b}}$ & $5.31^{\mathrm{b}}$ & $6.90^{\mathrm{A}, \mathrm{a}}$ & 0.46 & & & \\
\hline \multirow[t]{2}{*}{$S E L L$} & ORG & 4.65 & 5.12 & 5.43 & 5.30 & 0.18 & 0.057 & $<0.001$ & 0.720 \\
\hline & INO & 4.97 & 5.24 & 5.91 & 5.47 & 0.18 & & & \\
\hline \multirow[t]{2}{*}{$Z B P 1$} & ORG & 1.51 & 3.39 & 5.77 & 4.57 & 0.51 & 0.185 & $<0.001$ & 0.992 \\
\hline & INO & 2.15 & 3.98 & 6.43 & 4.98 & 0.51 & & & \\
\hline \multirow[t]{2}{*}{ NFE2L2 } & ORG & $5.41^{\mathrm{b}}$ & $5.52^{\mathrm{ac}}$ & $5.47^{\mathrm{A}, \mathrm{bc}}$ & $5.35^{\mathrm{A}, \mathrm{c}}$ & 0.20 & 0.025 & 0.002 & 0.017 \\
\hline & INO & $5.10^{\mathrm{b}}$ & $5.34^{\mathrm{a}}$ & $5.02^{\mathrm{B}, \mathrm{a}}$ & $4.21^{\mathrm{B}, \mathrm{c}}$ & 0.20 & & & \\
\hline \multirow[t]{2}{*}{$M P O$} & ORG & $4.16^{\mathrm{B}, \mathrm{b}}$ & $5.16^{\mathrm{a}}$ & $4.62^{\mathrm{ab}}$ & $4.26^{\mathrm{b}}$ & 0.40 & 0.206 & 0.003 & 0.026 \\
\hline & INO & $5.77^{\mathrm{A}, \mathrm{a}}$ & $6.02^{\mathrm{a}}$ & $4.01^{\mathrm{b}}$ & $4.54^{\mathrm{b}}$ & 0.40 & & & \\
\hline \multirow[t]{2}{*}{ SOD1 } & ORG & 4.66 & 5.05 & 5.91 & 5.91 & 0.34 & 0.264 & $<0.001$ & 0.661 \\
\hline & INO & 4.72 & 5.38 & 6.38 & 6.66 & 0.34 & & & \\
\hline \multirow[t]{2}{*}{ NOS2 } & ORG & 4.85 & 5.09 & 4.62 & 4.49 & 0.47 & 0.361 & 0.005 & 0.113 \\
\hline & INO & 6.04 & 6.17 & 4.23 & 4.20 & 0.47 & & & \\
\hline \multicolumn{10}{|l|}{ miRNA } \\
\hline miR-155 & ORG & $0.57^{\mathrm{B}, \mathrm{c}}$ & $0.64^{\mathrm{c}}$ & $1.82^{\mathrm{a}}$ & $1.01^{\mathrm{B}, \mathrm{b}}$ & 0.36 & 0.024 & $<0.001$ & 0.027 \\
\hline & INO & $0.89^{\mathrm{A}, \mathrm{c}}$ & $0.79^{\mathrm{c}}$ & $2.67^{\mathrm{a}}$ & $2.60^{\mathrm{A}, \mathrm{b}}$ & 0.36 & & & \\
\hline miR-125b & ORG & 0.88 & 0.88 & 1.08 & 0.83 & 0.16 & 0.036 & 0.893 & 0.712 \\
\hline & INO & 1.25 & 1.13 & 1.28 & 1.30 & 0.16 & & & \\
\hline miR-146a & ORG & 0.62 & 1.33 & 1.37 & 1.34 & 0.33 & 0.893 & 0.003 & 0.541 \\
\hline & INO & 0.93 & 1.44 & 1.45 & 0.89 & 0.33 & & & \\
\hline miR-223 & ORG & 1.57 & 1.11 & 1.07 & 0.99 & 0.17 & 0.707 & 0.164 & 0.702 \\
\hline & INO & 1.18 & 1.15 & 1.11 & 0.91 & 0.17 & & & \\
\hline miR-9 & ORG & 0.96 & 1.56 & 2.54 & 2.12 & 0.46 & 0.804 & $<0.001$ & 0.353 \\
\hline & INO & 1.34 & 0.97 & 1.91 & 1.88 & 0.46 & & & \\
\hline
\end{tabular}

\footnotetext{
${ }^{\mathrm{A}, \mathrm{B}}$ Differences $(P<0.05)$ between treatments within a given time point when the interaction was significant.

${ }^{\mathrm{a}-\mathrm{c}}$ Differences $(P<0.05)$ between time points within treatment when the interaction was significant.

${ }^{1} \mathrm{LSM}$ are $\log _{2}$ backtransformed.

${ }^{2}$ Greatest SEM is shown.

${ }^{3} P$-value for treatment $(\mathrm{T})$, day $(\mathrm{D})$, or their interaction $(\mathrm{T} \times \mathrm{D})$.
} 
sion in ORG calves at $21 \mathrm{~d}$ of age. An overall increase from birth to $1 \mathrm{~d}$ of life was observed for the expression of IRAK1 $(P=0.007)$, TRAF6 $(P=0.017)$, NFKB1 $(P=0.006), T N F(P<0.001)$, and $I L 1 B(P<0.001)$, whereas NFKBIA $(P<0.001)$ expression decreased during the same period (Table 3 ).

miRNA Related to the TLR Signaling Pathway. Maternal supplementation had an effect on miR$155(P=0.024)$ and miR-125b $(P=0.036)$, resulting in a downregulation in expression in ORG calves. The expression of miR-155, miR-146a, and miR-9 was upregulated $(P<0.004)$ from birth to $7 \mathrm{~d}$ of age. The expression of miR-223 was not affected by maternal treatment $(P=0.707)$ or time $(P=0.164$; Table 3$)$.

Cell Surface Adhesion, Pathogen DNA Binding, and Oxidative Stress. Expression of SELL tended to be greater $(P=0.057)$ in INO calves, with a marked increase $(P<0.001)$ from birth to $7 \mathrm{~d}$ of life. Overall expression of $Z B P 1$ also increased $(P<0.001)$ during the first week of life, but no treatment effect $(P$ $=0.185$ ) was detected (Table 3).

Expression of NFE2L2 had a significant interaction $(\mathrm{T} \times \mathrm{D}, P=0.017)$ due to greater $(P=0.02)$ expression in ORG calves than INO at 7 and $21 \mathrm{~d}$ of age. An overall time effect $(P=0.002)$ also was observed mainly due to a linear downregulation in its expression from 1 to $21 \mathrm{~d}$ in the INO calves. No treatment effect on $M P O$ expression $(P=0.206)$ was observed, but a significant interaction $(\mathrm{T} \times \mathrm{D}, P=0.026)$ occurred, where greater $(P=0.009)$ expression was observed in INO calves at birth. Expression of SOD1 and NOS2 was not affected $(P=0.264$ and 0.361$)$ by maternal treatment. Expression of SOD1 increased from birth to $7 \mathrm{~d}(P<0.001)$, whereas NOS2 decreased $(P=0.005)$ during the same period (Table 3 ). Supplementary Table S8 (http://dx.doi.org/10.3168/jds.2015-9359) reports effects of day specifically for gene and miRNA expression data.

\section{DISCUSSION}

Although exact mechanisms are unknown and the human and ruminant placental structure differ, in general, the human placenta is permeable to trace minerals (Smith et al., 1992). If the trace mineral is still chelated with the AA while crossing placental membranes, at least 15 to 20 different AA transport systems are expressed on the microvillous and basal membrane of the placenta that could allow for uptake via active transport (Jones et al., 2007; Larqué et al., 2013).

The mammary gland has a remarkable capacity to strictly regulate the secretion of trace elements in milk, even avoiding an imbalance when supplemented above requirements (Lonnerdal, 2007). Anionic and neutral
AA are transported by $\mathrm{Na}^{+}$-dependent or independent mechanisms, whereas cationic AA transfer has not been completely elucidated. In bovine and rat mammary tissue, AA transport is not $\mathrm{Na}^{+}$dependent (Shennan and Peaker, 2000).

\section{Growth Performance and Health}

Direct effects of ORG supplementation in enhancing bone growth are already well-established in poultry (Bao et al., 2010; Rao et al., 2013); thus, the trend for greater WH in ORG calves could have been influenced by the same mechanisms. Intrauterine bone development is strongly affected by growth factors such as insulin-like growth factor 2 , and epigenetic modifica-
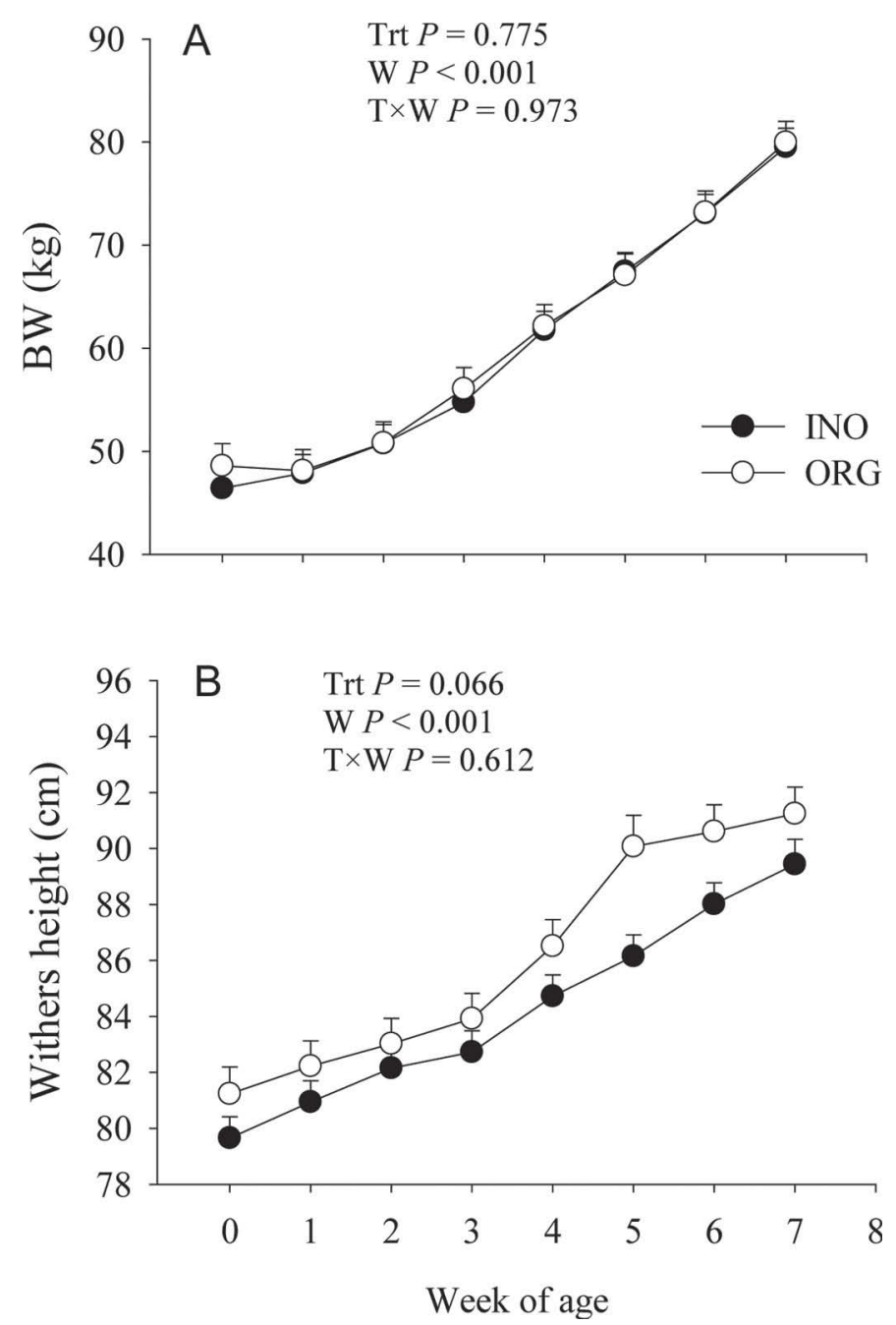

Figure 1. Body weight (A) and withers height (B) of calves born to dams fed a conventional diet supplemented with only inorganic (INO) or inorganic and organic (ORG) trace minerals during the last $30 \mathrm{~d}$ prepartum. Shown are $P$-values for main effects of treatment (Trt) and week $(W)$, and their interaction $(T \times W)$. 
tions modulate the pathway (Constancia et al., 2002; Tabano et al., 2010). Female rats that were exposed to intrauterine growth restriction had a reduction in bone size and mineral content and strength in part due to a decrease in endochondral ossification responsiveness (Chen et al., 2013). Proper cartilage and bone formation requires $\mathrm{Mn}$, as it is a cofactor for enzymes that synthesize chondroitin-sulfate side chains of proteoglycan molecules (Tomlinson et al., 2004). Whether the same mechanisms account for increasing $\mathrm{WH}$ in calves from cows fed ORG remains to be determined.

Although rectal temperature tended to be greater in INO than ORG calves, it did not surpass the normal physiological threshold (Scibilia et al., 1987). However, the $0.5^{\circ} \mathrm{C}$ increase in temperature in INO calves could be of biological significance, and as suggested by the TNF and NFKB1 expression, could reflect a transient inflammatory response. As such, it could have increased maintenance energy needs, hence impairing normal bone growth (Mundy, 1993; Lacey et al., 2009) and partly explaining the greater blood glucose concentrations in INO calves. Although not specifically measured in the present study, supplementing calves with an injectable trace mineral supplement containing $\mathrm{Se}, \mathrm{Cu}$, $\mathrm{Zn}$, and $\mathrm{Mn}$ enhanced the immune response (Teixeira et al., 2014). Thus, feeding ORG to dams could have elicited a better postnatal health status [e.g., enhancing gluconeogenic rate via Mn (Rognstad, 1981)] and sparing glucose from maintenance functions in favor of tissue growth. Clearly, differences between direct effects due to supplementation (prenatal) and the effects through maternal transfer (including colostrum) in the observed responses should be taken into account but could not be accurately discerned in the present study.

\section{Blood Biomarkers of Energy, Protein, and Inflammatory Metabolism}

The overall increases in GOT and GGT concentrations after colostrum intake could have been a result of intestinal absorption as immunoglobulins, as their content is higher in colostrum (Ontsouka et al., 2003; Bertoni et al., 2009), and not necessarily related to liver damage. As indices of liver damage, GOT and GGT in the newborn calf also could reflect a metabolic disorder of the dam such as subclinical acidosis (Lechowski, 1996), but based on previous work this increase appears to be a normal physiological response in the calf (Bertoni et al., 2009).

The neonatal capacity for FA oxidation and ketone body production in liver is low, but increases markedly during the first $24 \mathrm{~h}$ of life in response to intakes of colostrum and milk replacer (Blum, 2006). The increase of BHBA through the time of weaning is associated with the gradual intake of solid feed, which allows for rumen development and fermentation capacity, leading to production of VFA of which butyrate can be metabolized by rumen epithelium to BHBA and acetoacetate (Naeem et al., 2012). The decrease in NEFA concentrations after birth underscored the depletion of body fat stores of the calf.

The acute-phase response is characterized by the concomitant increase in concentration of positive APP such as ceruloplasmin, haptoglobin, and SAA, and the decrease of negative APP such as paraoxonase and albumin (Eckersall and Bell, 2010). Regardless of maternal nutrition, paraoxonase concentration remained within physiological levels for healthy calves, and the increase over time agrees with a previous study (Giordano et al., 2013). The increase in IL-6 concentration right after birth is indicative of an activation of the immune system. Together, these responses could be related to maturation of hepatic metabolic pathways, immune stimulation, and colostrum intake (Orro et al., 2008).

Despite FRAP values being already close to peak values at birth, the fact that MPO and ROM were undetectable at birth but were measurable at $1 \mathrm{~d}$ of age regardless of maternal treatment is suggestive of an activation of the oxidative stress response. Furthermore, the lower concentrations of MPO, ROM, and FRAP in ORG calves suggest a positive effect of maternal supplementation with ORG. Antioxidant activity has been positively correlated with increased FRAP (Benzie and Strain, 1996) and ORAC; thus, the higher FRAP and ORAC concentration in INO calves could be related to a greater need for neutralizing ROS production. Whether such an effect was induced in utero or via colostrum cannot be ascertained.

\section{PMNL Gene Expression Regulation of the Innate Immune Response}

The pro-inflammatory cascade can be initiated via different pathways, but both TLR2 and TLR4 are essential for neutrophil pathogen recognition and defense, including adhesion, generation of ROM, and release of chemokines (Sabroe et al., 2005). Despite the fact that calves in the ORG treatment had greater TLR2 expression, that response was not associated with upregulation of the pro-inflammatory pathway as indicated by the lower expression of the cytokine mediators IRAK1, NFKB1, and NFKBIA, a trend for lower MYD88, TRAF6, IL1B, the lack of change in $T N F$, and a trend for lower $S E L L$. It could be possible that maternal ORG resulted in a more efficient immune 
system such that calves maintained higher expression of TLR and did not need to upregulate expression of the pro-inflammatory signaling genes.

The marked increase in SELL expression during the first week of life, also detected previously (Osorio et al., 2013), likely reflects the potential of colostrum to trigger inflammation and prime the innate immune response. The same stimulus could be responsible for the temporal expression profile of $Z B P 1$, a cytosolic pathogen DNA recognition molecule that acts as a sensor to activate the innate immune response (Takaoka et al., 2007).

The transcription factor NFE2L2 regulates the expression of genes associated with detoxification, antioxidant, and anti-inflammatory cellular responses; hence, it plays an important protective role for the development of disease (Cardozo et al., 2013). Thus, the greater expression of NFE2L2 in ORG calves indicates they benefitted from the antioxidant and anti-inflammatory regulation controlled via NFE2L2. As opposed to the blood biomarkers related to oxidative stress (MPO, ROM, and FRAP), the fact that no treatment effect was observed in the expression of SOD1, MPO, and NOS2 demonstrates the existence of posttranscriptional regulation.

\section{miRNA Expression and Its Relationship with the TLR Pathway}

The expression of miR-155 is strongly induced by TLR pathogen sensing and pro-inflammatory cytokines (O'Connell et al., 2007), whereas miR-125b is inhibited (Tili et al., 2007). Despite the lack of statistical differences in systemic biomarkers of inflammation, the overall greater miR-155 expression in INO calves agrees with the overall greater oxidative stress status indicated by the greater concentrations of PON, ROM, MPO, and FRAP and the lower tocopherol. At the molecular level, the greater expression of miR-155 in INO calves agrees with the greater expression of most pro-inflammatory genes measured (e.g., NFKB1, TNF). The fact that both miR-155 and TNF expression were greater in INO calves might be explained by data demonstrating that induction of miR-155 by a pro-inflammatory stimulus such as LPS enhanced TNF translation (Tili et al., 2007). Thus, as the miRNA acts to repress the protein translation process, it is possible that enhanced mRNA synthesis (or greater half-life) is a compensatory response to counterbalance this inhibitory effect. Assuming that similar mechanisms of control exist in bovine, the greater overall expression of miR-125b in INO calves appears unrelated to oxidative stress or inflammatory status. Furthermore, a relationship between TLR and miR-125b in the present study is not evident because the interaction effect for $T L R 4$ expression was due to a decrease in expression at $21 \mathrm{~d}$ in INO calves. Further studies involving pro-inflammatory challenges are required to establish more precisely mechanisms of miRNA regulation in neonatal calf immune cells.

The expression of miR-146a can be induced by bacterial activation of cell surface TLR (TLR2, TLR4, TLR5) and also by TNF and IL1B treatment in an NFKBdependent manner (Taganov et al., 2006). The genes IRAK1 and TRAF6 are direct targets of miR-146a, and their downregulation over time regardless of treatment via the miRNA may function as a negative feedback regulatory mechanism (i.e., miR-146a expression may be critical to prevent uncontrolled inflammation). The increased expression of miR-9 during the first week of life was likely related to TLR4 activation in an NFKBdependent manner, operating in a negative feedback control by exerting close control on the expression of key members of the NFKB pathway (Bazzoni et al., 2009).

The present data demonstrate the plasticity of miRNA expression in bovine neutrophils during the neonatal period, as well as how maternal diet supplementation with organic trace minerals can influence growth and the immune response. Our results indicate that calves from dams fed ORG during the last $30 \mathrm{~d}$ of gestation had a lower oxidative stress status during the postnatal period. Although this was not measured directly, we surmise that this effect benefited immune function as reflected in the downregulation of inflammatory mRNA and miRNA. If systemic inflammation was indeed reduced, additional energy (e.g., glucose) would have been spared for growth, and partly explain the trend for greater $\mathrm{WH}$ around weaning time. Additional research in this area to clarify the mechanisms at play seems warranted.

\section{ACKNOWLEDGMENTS}

Carolina Jacometo was supported in part by a fellowship from Coordenação de Aperfeiçoamento de Pessoal de Nível Superior (CAPES) from the Brazilian Ministry of Education, and by Hatch funds under project ILLU538-914, National Institute of Food and Agriculture, Washington, DC.

\section{REFERENCES}

Aguilera, O., A. F. Fernandez, A. Munoz, and M. F. Fraga. 2010. Epigenetics and environment: A complex relationship. J. Appl. Physiol. 109:243-251.

Attig, L., A. Gabory, and C. Junien. 2010. Nutritional developmental epigenomics: Immediate and long-lasting effects. Proc. Nutr. Soc. 69:221-231.

Bao, Y. M., M. Choct, P. A. Iji, and K. Bruerton. 2010. Trace mineral interactions in broiler chicken diets. Br. Poult. Sci. 51:109-117. 
Bazzoni, F., M. Rossato, M. Fabbri, D. Gaudiosi, M. Mirolo, L. Mori, N. Tamassia, A. Mantovani, M. A. Cassatella, and M. Locati. 2009. Induction and regulatory function of miR-9 in human monocytes and neutrophils exposed to proinflammatory signals. Proc. Natl. Acad. Sci. USA 106:5282-5287.

Benzie, I. F., and J. J. Strain. 1996. The ferric reducing ability of plasma (FRAP) as a measure of "antioxidant power": The FRAP assay. Anal. Biochem. 239:70-76.

Bertoni, G., A. Ferrari, A. Gubbiotti, and E. Trevisi. 2009. Blood indices calves: relationship with mother values and changes in the first days of life. Ital. J. Anim. Sci. 8(Suppl. 2):595-597.

Bionaz, M., E. Trevisi, L. Calamari, F. Librandi, A. Ferrari, and G. Bertoni. 2007. Plasma paraoxonase, health, inflammatory conditions, and liver function in transition dairy cows. J. Dairy Sci. 90:1740-1750.

Blum, J. W. 2006. Nutritional physiology of neonatal calves. J. Anim. Physiol. Anim. Nutr. (Berl.) 90:1-11.

Bustin, S. A., V. Benes, J. A. Garson, J. Hellemans, J. Huggett, M. Kubista, R. Mueller, T. Nolan, M. W. Pfaffl, G. L. Shipley, J. Vandesompele, and C. T. Wittwer. 2009. The MIQE guidelines: Minimum information for publication of quantitative real-time PCR experiments. Clin. Chem. 55:611-622.

Cao, G., and R. L. Prior. 1999. Measurement of oxygen radical absorbance capacity in biological samples. Methods Enzymol. 299:5062.

Cardozo, L. F., L. M. Pedruzzi, P. Stenvinkel, M. B. Stockler-Pinto, J. B. Daleprane, M. Leite Jr., and D. Mafra. 2013. Nutritional strategies to modulate inflammation and oxidative stress pathways via activation of the master antioxidant switch Nrf2. Biochimie 95:1525-1533.

Chen, H., S. Miller, R. H. Lane, and L. J. Moyer-Mileur. 2013. Intrauterine growth restriction decreases endochondral ossification and bone strength in female rats. Am. J. Perinatol. 30:261-266.

Chen, J. Q., P. Szodoray, and M. Zeher. 2015. Toll-like receptor pathways in autoimmune diseases. Clin. Rev. Allergy Immunol. http:// dx.doi.org/10.1007/s12016-015-8473-z.

Constancia, M., M. Hemberger, J. Hughes, W. Dean, A. FergusonSmith, R. Fundele, F. Stewart, G. Kelsey, A. Fowden, C. Sibley, and W. Reik. 2002. Placental-specific IGF-II is a major modulator of placental and fetal growth. Nature 417:945-948.

Eckersall, P. D., and R. Bell. 2010. Acute phase proteins: Biomarkers of infection and inflammation in veterinary medicine. Vet. J. 185:23-27.

Eulalio, A., E. Huntzinger, and E. Izaurralde. 2008. Getting to the root of miRNA-mediated gene silencing. Cell 132:9-14.

Gantier, M. P. 2013. The not-so-neutral role of microRNAs in neutrophil biology. J. Leukoc. Biol. 94:575-583.

Giordano, A., M. C. Veronesi, G. Rossi, F. Pezzia, M. Probo, L. Giori, and S. Paltrinieri. 2013. Serum paraoxonase-1 activity in neonatal calves: Age related variations and comparison between healthy and sick animals. Vet. J. 197:499-501.

Hammon, H. M., J. Steinhoff-Wagner, U. Schonhusen, C. C. Metges, and J. W. Blum. 2012. Energy metabolism in the newborn farm animal with emphasis on the calf: Endocrine changes and responses to milk-born and systemic hormones. Domest. Anim. Endocrinol. 43:171-185.

Hidiroglou, M. 1980. Trace elements in the fetal and neonate ruminant: A review. Can. Vet. J. 21:328-335.

Johnson, J. L., S. M. Godden, T. Molitor, T. Ames, and D. Hagman. 2007. Effects of feeding heat-treated colostrum on passive transfer of immune and nutritional parameters in neonatal dairy calves. J. Dairy Sci. 90:5189-5198.

Jones, H. N., T. L. Powell, and T. Jansson. 2007. Regulation of placental nutrient transport-A review. Placenta 28:763-774.

Lacey, D. C., P. J. Simmons, S. E. Graves, and J. A. Hamilton. 2009. Proinflammatory cytokines inhibit osteogenic differentiation from stem cells: implications for bone repair during inflammation. Osteoarthr. Cartil. 17:735-742.

Larqué, E., M. Ruiz-Palacios, and B. Koletzko. 2013. Placental regulation of fetal nutrient supply. Curr. Opin. Clin. Nutr. Metab. Care 16:292-297.
Lechowski, R. 1996. Changes in the profile of liver enzymes in newborn calves induced by experimental, subclinical acidosis in pregnant cows and osmotic diarrhoea. Vet. Res. Commun. 20:351-365.

Lim, L. P., N. C. Lau, P. Garrett-Engele, A. Grimson, J. M. Schelter, J. Castle, D. P. Bartel, P. S. Linsley, and J. M. Johnson. 2005. Microarray analysis shows that some microRNAs downregulate large numbers of target mRNAs. Nature 433:769-773.

Lonnerdal, B. 2007. Trace element transport in the mammary gland. Annu. Rev. Nutr. 27:165-177.

Moyes, K. M., J. K. Drackley, D. E. Morin, and J. J. Loor. 2010. Greater expression of TLR2, TLR4, and IL6 due to negative energy balance is associated with lower expression of HLA-DRA and HLA-A in bovine blood neutrophils after intramammary mastitis challenge with Streptococcus uberis. Funct. Integr. Genomics 10:53-61.

Mundy, G. R. 1993. Cytokines and growth factors in the regulation of bone remodeling. J. Bone Miner. Res. 8(Suppl. 2):S505-S510.

Naeem, A., J. K. Drackley, J. Stamey, and J. J. Loor. 2012. Role of metabolic and cellular proliferation genes in ruminal development in response to enhanced plane of nutrition in neonatal Holstein calves. J. Dairy Sci. 95:1807-1820.

NRC. 2001. Nutrient Requirements of Dairy Cattle. 7th rev. ed. National Academy Press, Washington, DC.

O'Connell, R. M., K. D. Taganov, M. P. Boldin, G. Cheng, and D. Baltimore. 2007. MicroRNA-155 is induced during the macrophage inflammatory response. Proc. Natl. Acad. Sci. USA 104:1604-1609.

Ontsouka, C. E., R. M. Bruckmaier, and J. W. Blum. 2003. Fractionized milk composition during removal of colostrum and mature milk. J. Dairy Sci. 86:2005-2011.

Orro, T., S. Jacobsen, J. P. LePage, T. Niewold, S. Alasuutari, and T. Soveri. 2008. Temporal changes in serum concentrations of acute phase proteins in newborn dairy calves. Vet. J. 176:182-187.

Osorio, J. S., E. Trevisi, M. A. Ballou, G. Bertoni, J. K. Drackley, and J. J. Loor. 2013. Effect of the level of maternal energy intake prepartum on immunometabolic markers, polymorphonuclear leukocyte function, and neutrophil gene network expression in neonatal Holstein heifer calves. J. Dairy Sci. 96:3573-3587.

Osorio, J. S., R. L. Wallace, D. J. Tomlinson, T. J. Earleywine, M. T. Socha, and J. K. Drackley. 2012. Effects of source of trace minerals and plane of nutrition on growth and health of transported neonatal dairy calves. J. Dairy Sci. 95:5831-5844.

Rao, S. V., B. Prakash, K. Kumari, M. V. Raju, and A. K. Panda. 2013. Effect of supplementing different concentrations of organic trace minerals on performance, antioxidant activity, and bone mineralization in Vanaraja chickens developed for free range farming. Trop. Anim. Health Prod. 45:1447-1451.

Rognstad, R. 1981. Manganese effects on gluconeogenesis. J. Biol. Chem. 256:1608-1610.

Rosenberg, G. 1979. Clinical Evaluation of Cattle. G. Rosenberg, ed. Verlag Paul Parey, Berlin, Germany.

Sabroe, I., S. K. Dower, and M. K. Whyte. 2005. The role of toll-like receptors in the regulation of neutrophil migration, activation, and apoptosis. Clin. Infect. Dis. 41(Suppl. 7):S421-S426.

Scibilia, L. S., L. D. Muller, R. S. Kensinger, T. F. Sweeney, and P. R. Shellenberger. 1987. Effect of environmental temperature and dietary fat on growth and physiological responses of newborn calves. J. Dairy Sci. 70:1426-1433.

Seo, J., J. S. Osorio, and J. J. Loor. 2013. Purinergic signaling gene network expression in bovine polymorphonuclear neutrophils during the peripartal period. J. Dairy Sci. 96:7675-7683.

Shennan, D. B., and M. Peaker. 2000. Transport of milk constituents by the mammary gland. Physiol. Rev. 80:925-951.

Skinner, J. G., R. Brown, A. Li, and L. Roberts. 1991. Bovine haptoglobin response in clinically defined field conditions. Vet. Rec. 128:147-149.

Smith, C. H., A. J. Moe, and V. Ganapathy. 1992. Nutrient transport pathways across the epithelium of the placenta. Annu. Rev. Nutr. $12: 183-206$

Spears, J. W., and W. P. Weiss. 2008. Role of antioxidants and trace elements in health and immunity of transition dairy cows. Vet. J. 176:70-76. 
Sunderman, F. W., and S. Nomoto. 1970. Measurement of human serum ceruloplasmin by Its p-phenylenediamine oxidase activity. Clin. Chem. 16:903-910.

Swecker, W. S. Jr. 2014. Trace mineral feeding and assessment. Vet. Clin. North Am. Food Anim. Pract. 30:671-688.

Tabano, S., P. Colapietro, I. Cetin, F. R. Grati, S. Zanutto, C. Mando, P. Antonazzo, P. Pileri, F. Rossella, L. Larizza, S. M. Sirchia, and M. Miozzo. 2010. Epigenetic modulation of the IGF2/H19 imprinted domain in human embryonic and extra-embryonic compartments and its possible role in fetal growth restriction. Epigenetics: Official Journal of the DNA Methylation Society 5:313-324.

Taganov, K. D., M. P. Boldin, K. J. Chang, and D. Baltimore. 2006. NF-kappaB-dependent induction of microRNA miR-146, an inhibitor targeted to signaling proteins of innate immune responses. Proc. Natl. Acad. Sci. USA 103:12481-12486.

Takaoka, A., Z. Wang, M. K. Choi, H. Yanai, H. Negishi, T. Ban, Y. Lu, M. Miyagishi, T. Kodama, K. Honda, Y. Ohba, and T. Taniguchi. 2007. DAI (DLM-1/ZBP1) is a cytosolic DNA sensor and an activator of innate immune response. Nature 448:501-505.

Teixeira, A. G., F. S. Lima, M. L. Bicalho, A. Kussler, S. F. Lima, M. J. Felippe, and R. C. Bicalho. 2014. Effect of an injectable trace mineral supplement containing selenium, copper, zinc, and manganese on immunity, health, and growth of dairy calves. J. Dairy Sci. 97:4216-4226.

Tili, E., J. J. Michaille, A. Cimino, S. Costinean, C. D. Dumitru, B. Adair, M. Fabbri, H. Alder, C. G. Liu, G. A. Calin, and C. M. Croce. 2007. Modulation of miR-155 and miR-125b levels following lipopolysaccharide/TNF-alpha stimulation and their possible roles in regulating the response to endotoxin shock. J. Immunol. 179:5082-5089.

Tomlinson, D. J., C. H. Mulling, and T. M. Fakler. 2004. Invited review: Formation of keratins in the bovine claw: Roles of hormones, minerals, and vitamins in functional claw integrity. J. Dairy Sci. $87: 797-809$.

Trevisi, E., M. Amadori, S. Cogrossi, E. Razzuoli, and G. Bertoni. 2012. Metabolic stress and inflammatory response in high-yielding, periparturient dairy cows. Res. Vet. Sci. 93:695-704.

Trevisi, E., G. Bertoni, R. Lombardelli, and A. Minuti. 2013. Relation of inflammation and liver function with the plasma cortisol response to ACTH in early lactating dairy cows. J. Dairy Sci. 96:5712-5722.

Vandesompele, J., K. De Preter, F. Pattyn, B. Poppe, N. Van Roy, A. De Paepe, and F. Speleman. 2002. Accurate normalization of realtime quantitative RT-PCR data by geometric averaging of multiple internal control genes. Genome Biology 3(7):RESEARCH0034.

Wang, R. L., J. G. Liang, L. Lu, L. Y. Zhang, S. F. Li, and X. G. Luo. 2013. Effect of zinc source on performance, zinc status, immune response, and rumen fermentation of lactating cows. Biol. Trace Elem. Res. 152:16-24.

Wolowczuk, I., C. Verwaerde, O. Viltart, A. Delanoye, M. Delacre, B. Pot, and C. Grangette. 2008. Feeding our immune system: Impact on metabolism. Clin. Dev. Immunol. 2008:639803.

Wu, L., and J. G. Belasco. 2005. Micro-RNA regulation of the mammalian lin-28 gene during neuronal differentiation of embryonal carcinoma cells. Mol. Cell. Biol. 25:9198-9208. 